\title{
Lökositoklastik Vaskülit Bulguları ile Ortaya Çıkan Ülseratif Kolit
}

\author{
Ulcerative Colitis Presented with Leucocytoclastic Vasculitis Findings \\ Seval DOĞRUK KAÇAR ${ }^{1}$, Pınar ÖZUĞUZ1 ${ }^{1}$ Kasım DEMiR² ${ }^{2}$, Tekin TÜRKSOY ${ }^{3}$, Gürsel ACARTÜRK²
}

\author{
${ }^{1}$ Afyon Kocatepe Üniversitesi Tıp Fakültesi, Deri ve Zührevi Hastalıkları AD, Afyonkarahisar \\ ${ }^{2}$ Afyon Kocatepe Üniversitesi Tıp Fakültesi, İç Hastalıkları AD, Gastroenteroloji Bölümü, Afyonkarahisar \\ ${ }^{3}$ Afyon Kocatepe Üniversitesi Tıp Fakültesi, İç Hastalıkları AD, Afyonkarahisar
}

\begin{abstract}
öz
Ülseratif kolit kolonun inflamatuvar bir hastalığı olup pek çok mukokutanöz bulgu ile birlikte görülebilir. Burada lökositoklastik vaskülit tanısı alan deri lezyonlarının ortaya çıkmasından kısa süre sonra karın ağrısı ve hematokezya şikayetleri ile başvuran ve ülseratif kolit tanısı alan 46 yaşındaki erkek hasta sunulmuştur.
\end{abstract}

Anahtar Kelimeler: Ülseratif kolit, lökositoklastik vaskülit, deri bulguları

\begin{abstract}
Ulcerative colitis is an inflammatory disease that is associated with many mucocutaneous findings. Here, we report a 46 year old male patient, short after skin lesions diagnosed as leucocytoclastic vasculitis, he presented with abdominal pain and hematochezia and diagnosed as ulcerative colitis.
\end{abstract}

Keywords: Ulcerative colitis, leukocytoclastic vasculitis, skin findings 


\section{Giriş̧}

Ülseratif kolit; kolonun tekrarlayan, inflamatuvar ve ülseratif bir hastalığı olup sıklıkla kanlı diyare ve karın ağrıları ile ortaya çıkar. Piyoderma gangrenozum, eritema nodozum, akneiform erupsiyonlar, aftlar, immünbüllöz hastalıklar, ürtikeryal vaskülit ve pyostomatitis vejetans gibi pek çok mukokutanöz bulgu ülseratif kolite eşlik edebilir ve bu bulgular sıklıkla barsak bulgularından sonra görülür (1).

Lökositoklastik vaskülit primer deri tutulumu ile seyreden bir küçük damar vaskülitidir. Etyolojide ilaçlar, infeksiyonlar, otoimmün hastalıklar, gıda ve gıda katkı maddeleri ve maligniteler gibi pek çok faktör yer alır. En sık alt ekstremitelerde başlayan simetrik palpabl purpura olarak görülür. Bu hastalarda sistemik tutulum bulguları izlendiğinde Henöch Schönlein vasküliti, Wegener granülomatozu, Poliarteritis nodoza, mikst kriyoglobulinemi gibi diğer vaskülit nedenleri düşünülmelidir. Gastrointestinal tutuluma bağlı karın ağrısı ve gastrointestinal kanama görülebilir (2). Burada lökositoklastik vaskülit tanısı alan deri bulgularının ortaya çıkmasından kısa süre sonra gelişen hematokezya ve karın ağrısı sebebiyle değerlendirilerek ülseratif kolit tanısı alan bir erkek hasta sunulmuştur.

\section{OLGU SUNUMU}

Kırk altı yaşındaki erkek hasta dermatoloji polikliniğine 1 hafta içinde ayak bileklerinde başlayıp karına yayılan döküntüleri sebebiyle başvurdu. Hastanın dermatolojik muayenesinde bilateral alt ekstremitelerden göbek altına kadar uzanan

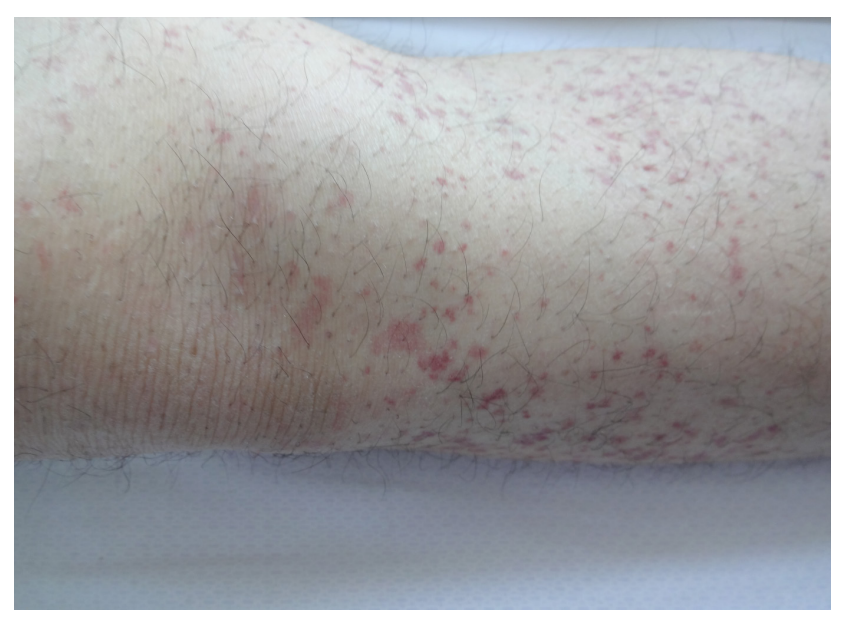

Şekil I: Alt ekstremitelerde purpurik makülopapüller. yaygın purpurik basmakla solmayan palpabl makül ve papüller izlendi (Şekil I). Hastanın sorgulamasında başvuru sabahı başlayan hafif ka-

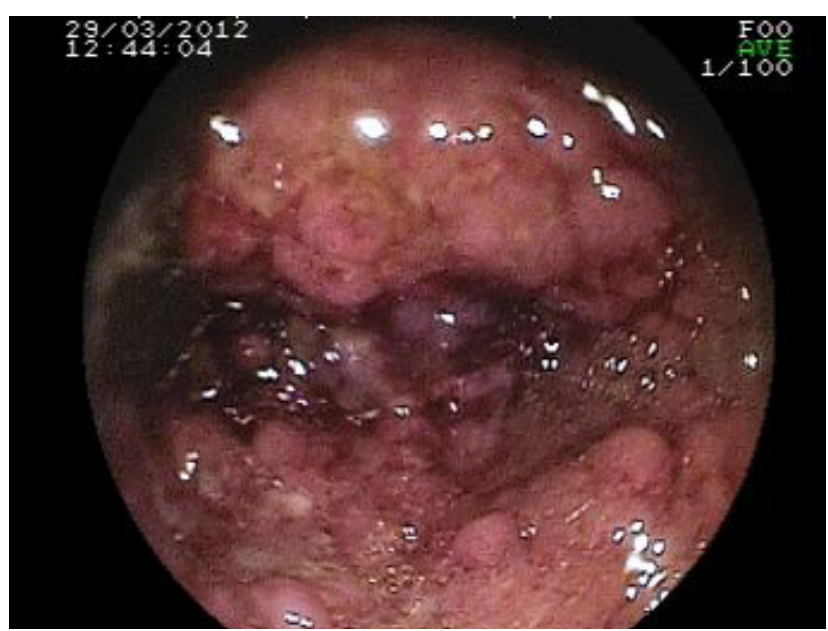

Şekil II: Kolonoskopide diffüz mukozal eritem ve yaygın ülserler.

rın ağrısı ve kanlı dışkılama şikayeti olduğu ayrıca 2 ay kadar önce şiddetli karın ağrısı sebebiyle mezenter iskemisi düşünülerek yoğun bakımda takip ve tedavi edildiği öğrenildi. Yapılan laboratuar incelemede artmış sedimentasyon hızı, normal CRP, lökosit sayısı, böbrek ve karaciğer fonksiyon testleri yanında viral hepatit markerları da negatif idi. Cilt lezyonlarından deri biyopsisi alınan hasta gastroenteroloji tarafından değerlendirildi ve yapılan kolonoskopide diffüz mukozal eritem ve ödem yanında multipl mukozal ülserler-ülseratif kolit lehine bulgular (Şekil II) saptandı. Günlük ishal sayısının ve kanlı dışkılamasının fazla olması, yüksek sedimantasyon hızı ve fizik muayenedeki batın bulguları dikkate alınarak, şiddetli ülseratif kolit tanısı ile 40 mg metilprednisolon ve mesalazin (oral 4gr/ gün ve rektal $8 \mathrm{gr} / \mathrm{gün}$ ) başlandı. Takipte kolit kliniği ve döküntülerde gerileme başladı. Hastanın steroidi oral $30 \mathrm{mg}$ prednisolona geçilip, haftalık $5 \mathrm{mg}$ doz azaltılması planlandı. Deri lezyonları ve gastrointestinal şikayetleri kısa sürede gerileyen hasta yatışının 17. gününde taburcu edildi. Steroidi azaltılarak kesilen hasta mesalazin tedavisi ile 8 aydır takip edilmektedir.

\section{TARTIŞMA}

Lökositoklastik vaskülit, histolojik olarak postkapiller venüllerin etrafında nötrofilik infiltrasyon ve nükleer atıklar, damar duvarında 
fibrin depozitleri, eritrosit ekstravazasyonu gibi bulguların izlendiği küçük damar vaskülitidir. Patogenezinde antijene karşı gelişen immünolojik yanıta bağlı oluşan immün komplekslerin damar duvarında yaptığı vasküler hasar yer alır. Bu immünolojik yanıtı çeşitli antijenler oluşturabilir. Özellikle beta-laktam antibiyotikler, nonsteroid antiinflamatuarlar ve diüretikler gibi ilaçlar, başta viral ve bakteryel infeksiyonlaryanında pekçok sistemik hastalıkta lökositoklastik vaskülit tablosu görülebilir. Simetrik palpabl purpura olarak başlayan lezyonların yanı sıra maküler, ürtiker benzeri, plak şeklinde, vezikülobüllöz, hemorajik ve nekrotik lezyonlarda görülebilir. Ancak purpura tüm lezyonlara sıklıkla eşlik eder. Deri en sık tutulan organ olmasına rağmen böbrekler, gastrointestinal sistem, eklemler ve daha nadir olarak akciğer, kalp ve santral sinir sistemi de tutulumu olabilir. Bunun yanında ateş, halsizlik, yaygın atralji ve miyalji de görülebilir (2). Bizim olgumuz alt ekstremitelerde palpabl purpuraları sebebiyle dermatoloji kliniğine başvurdu ve başvuru anında eşlik eden gastrointestinal bulguları sebebiyle ilk olarak vaskülit sistemik tutulum düşünüldü. Ancak şiddetlenerek devam eden şikayetleri sebebiyle kolonoskopi yapıldı. Rektumdan itibaren diffüz tutulum olması nedeniyle ülseratif kolit tanısı ile tedavileri düzenlendi.

Ülseratif kolitte görülen deri bulgularını patogenetik mekanizmalarına göre üç ayrı grupta incelemek mümkündür (Tablo I) (3). Lökositoklastik vaskülit ve ülseratif kolit arasında tam bir ilişki saptamak mümkün olmamakla beraber bu güne kadar birliktelik bildirilmiş vakalar vardır (4-7). Burada vaskülit oluşumuna yol açan immün komplekslerin submukozal lenfoid dokuda ortaya çıkan fekal antijenlere

Tablo I: Ülseratif kolit ile beraber görülen mukokutanöz bulguların patogeneze göre gruplandırılması

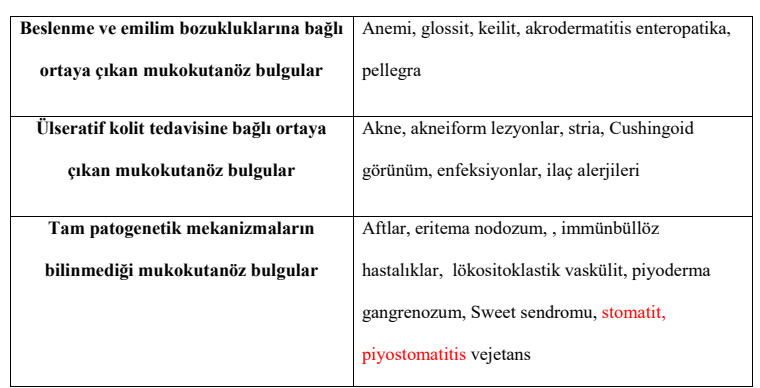

bağlı oluştuğu düşünülür (8). Bunun yanında ülseratif kolit genetik ve çevresel faktörlerin etkisi ile oluşur. Akut gastroenterit atağına sebep olan ajanlar ülseratif kolit başlaması ya da alevlenmesine yol açabilir. Bu ajanların vaskülit oluşumunda da rol aldığı bilinmektedir. Böyle bir faktör her iki hastalığı başlatan neden olabilir. Öte yandan ülseratif kolit beraberinde görülen deri bulgularının hiç biri hastalığa özel bulgular değildir ve koinsidental olarakta birliktelik gösterebilir. Şüpheli ilaç kullanımı öyküsü olmayan, CRP ve viral markırları negatif olan hastamızda bunu ekarte etmek mümkün olmamıştır ancak tedavi ile ülseratif kolit kliniğinde ve vaskülitik lezyonlarda hızlı bir solma olması ülseratif kolit ilişkisini destekler.

Sonuç olarak bu yazıda, inflamatuvar barsak hastalığı kliniği henüz ortaya çıkmadan saptanan bir lökositoklastik vaskülit olgusu sunulmuş olup, koinsidental de olsa, bu birlikteliğe dikkat çekilmiştir.

\section{KAYNAKLAR}

1. Arai S, Katsuoka K. Cutaneous manifestations with ulcerative colitis. Nihon Rinsho 1999;57(11):2571-4.

2. Cox NH, Coulson IH. Systemic diseases and the skin. In: Burns T,Breathnach S, Cox N, Griffiths C (Editors). Rook's Textbook of Dermatology. 8th Edition, UK: Blackwell Publishing, 201062.50.

3. Timani S, Mutasim DF. Skin manifestations of inflammatory bowel disease. Clin Dermatol 2008;26(3):265-73.

4. Martin D, Handler T, McDermott J. Leucocytoclastic vasculitis in severe ulcerative colitis. Mil Med 2011;176(5):581-3.

5. Akbulut S, Ozaslan E. Topal F, Albayrak L, Kayhan B, Efe C. Ulcerative colitis presenting as leukocytoclastic vasculitis of skin. World J Gastroenterol 2008;14(15):2448-50.

6. lannone F, Scioscia C. Musio A, Poscitelli D, Lapadula G. Leucocytoclastic vasculitis as onset symptom of ulcerative colitis. Ann Rheum Dis 2003;62(8):785-6.

7. Newton JA, McGibbon DH, Marsden RA. Leucocytoclastic vasculitis and angio-oedema associated with infiammatory bowel disease. Clin Exp Dermatol 1984;9(6):618-23.

8. Tripodi Cutrì F, Salerno R, Lo Schiavo A, Gravina AG, Romano $M$, Ruocco E. Ulcerative colitis associated with leukocytoclastic vasculitis of the skin. Dig Liver Dis 2009;41(7):42-4. 